\title{
Comparative techno-economic analysis of power system with and without renewable energy sources
}

\author{
Hephzibah Jose Queen ${ }^{1}$, Jayakumar J. ${ }^{2}$, Deepika T. J. ${ }^{3}$ \\ ${ }^{1,2}$ Department of Electrical and Electronics Engineering, Karunya Institute of Technology and Sciences, \\ Coimbatore, India \\ ${ }^{3}$ Department of Electrical and Electronics Engineering, Sona College of Technology, Salem, India
}

\begin{tabular}{l} 
Article Info \\
\hline Article history: \\
Received Feb 20, 2021 \\
Revised Oct 21, 2021 \\
Accepted Oct 28, 2021 \\
\hline
\end{tabular}

\section{Keywords:}

Cost analysis

Grid

L-Index

Renewable energy sources

Voltage stability analysis

\begin{abstract}
The primary aim of this work is to feature the advantages of integrating natural source of energy from the solar and wind to the prevailing electric power systems. Two types of analysis are carried out in two test systems (standard and modified test systems) and the outcome of the test systems are compared. The two analyses are technical analysis and economic analysis. The stability of the voltage is analyzed under technical analysis and the price of energy consumed from the electric grid is calculated and analyzed under the economic analysis. Dynamic hourly load data, hourly solar radiation, hourly wind velocity, and dynamic electricity prices are considered for the standard IEEE system and modified test system (with the integration of RES). Voltage stability index (L-Index) and price of the electricity consumed from electric grid are found for standard test system and the outcome is compared with the outcome of modified test systems. MATLAB coding is done for techno-economic analysis for both test systems. It is inferred from the outcome that the integration of renewable energy sources fairly contributes to the economic benefit of the system by lowering the power purchased from the grid and enhance the stability of the system.
\end{abstract}

This is an open access article under the CC BY-SA license.

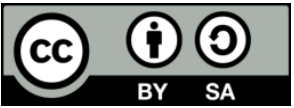

\section{Corresponding Author:}

Hephzibah Jose Queen

Department of Electrical and Electronics Engineering

Karunya Institute of Technology and Sciences

Karunya Nagar, Coimbatore, Tamil Nadu, India

Email: hephzijose@gmail.com

\section{INTRODUCTION}

Nowadays, most of the countries developed several solutions to produce clean and green energy. Among them is the integration of renewable energy sources (RES) [1] to the electric grid which benefits both the environment and humans [2]. In this work, the benefits of integrating RES are analyzed in two different aspects. One essential technical aspect that cannot be overlooked is its voltage stability. The economic aspect of analyzing a system is to compute the operation costs incurred. Both technical and economic aspects are presented in this paper with a basis of power flow analysis.

In the examination of power systems, load flow studies are critical. The total real and reactive power flow, as well as the magnitude and phase angle of the voltages at each bus, may be determined using a load flow analysis for a system [3]. When adjustments to the power system architecture are required, a load flow analysis is used to determine the condition of each operational stage. This status will assist us in maintaining overall control, ensuring stability, and determining whether or not economic restrictions are met. Load flow studies are utilized not only for system planning and design, but also for evaluating changes in the current system [4]. Load flow studies provide steady state solutions of bus voltages and power flow information for a given load condition [5]. With the load and operating conditions, the power flow and voltages at the buses will fluctuate dynamically. 
In a successful power system, voltage stability should be kept within safe ranges. The term "voltage stability" is described as "the ability of a power system to maintain acceptable voltage in the system both under normal conditions and also after being subjected to a disturbance [6]-[9]." There are a variety of methods for determining voltage stability [10]. They are L-Index [11], P-V curve, $\mathrm{V} / \mathrm{V}_{0}$ index, modal analysis, line stability index $\mathrm{L}_{\mathrm{mn}}$, line stability index, FVSI, line stability index LQP, and line stability indices VCPI [12], [13]. Among all the most simple and effective way to find the voltage stability is L-Index.

If the energy generation by the renewable energy sources (RES) is higher than the demand, electrical energy is fed in the utility grid respectively if the energy generation by RES is lower than the required demand, additional energy is needed from the utility grid [14], [15]. To minimize the operating costs of the system, a battery storage unit can be added to the grid. Furthermore, dynamic pricing represents a good opportunity to minimize the total operating costs for a specific time period (here: 24 hours). Dynamic pricing means that the electricity price varies depending on supply and demand instead of being fixed. The economic analysis shows the cost benefit of the integration of renewable energy sources.

In the MATLAB coding environment, the techno-economic analysis of the system incorporated with the renewable energy sources (solar, PV) [16] are carried out [17]-[20]. To ensure practical applications of the proposed analysis, time-varying data of load, solar radiation, wind velocities and grid electricity costs are considered. Both the voltage stability and cost analysis with and without RES are carried out in standard IEEE test beds (IEEE 14 bus system and IEEE 30 bus system) [21]-[30].

The paper comprises three sections, in which the section 2 describes the techno-economic analysis, section 3 explains the proposed algorithm of techno-economic analysis. Section 4 gives the IEEE standard bus system data, renewable energy sources design and corresponding data. The techno-economic analysis is carried out in the MATLAB platform on IEEE 14 and 30 system and a comparative study of the system with and without RES is carried out in section 5 .

\section{TECHNICAL AND ECONOMICAL ANALYSIS}

The provided technical-economical assessment of the studied system takes into account both economic and technical aspects of study in terms of voltage regulation and power acquired from the grid. The analysis is split into three stages namely-power flow analysis, technical (stability) analysis and economic (cost) analysis. Each of these analyses along with necessary flowcharts and equations is detailed in this section.

\subsection{Power flow analysis}

Power flow, or load flow, is widely used in power system operation and planning. Any electrical system study necessitates the estimation of line and node parameters such as voltage, current, and power. In this paper, newton-raphson (NR) method of power flow analysis is used to compute the system parameters.

\subsection{Technical: stability analysis}

Voltage stability within the permissible level must always be sustained for a reliable electrical network [31]-[35]. The L-Index [36], which is a simple but effective statistical technique for evaluating voltage stability [37], [38] is considered in this paper. L-index sensitivities will be used to determine the control actions. L-Index is calculated for load bus. L-index in [1] has been adopted in this paper for on-line voltage stability enhancemnt. It computed as (1),

$$
L_{j}=\left|1-\sum_{i=1}^{g} F_{j i} \frac{V_{i}}{V_{j}}\right|
$$

where,

- V denotes the Voltage at the bus

- $\quad \mathrm{i}$ denotes the generator bus

- $\mathrm{j}$ denotes the load bus

- $1, \ldots, \mathrm{g}$ are the generators

- $\quad \mathrm{n}$ is the no of buses

The admittance matrix computation according to (2) can be used to compute the term Fji

$$
\left[V_{l} I_{g}\right]=\left[Z_{l l} F_{l g} K_{g l} Y_{g g}\right]\left[I_{l} V_{g}\right]
$$

where

- $\quad F_{l g}$ is calculated as $\left[F_{l g}\right]=-\left[Y_{l l}\right]^{-1}\left[Y_{l g}\right]$

- $\quad Y_{l l}$ denotes self-admittance at the node $l$

- $Y_{l g}$ denotes mutual admittance between node $l$ and $g$. 
The level of voltage stability is shown by the local indicator-index. Its range can be anywhere from 0 to 1 . When there is no load on this load bus, the Local Indicator index score is 0 . Voltage stability has collapsed when the local indicator index value is 1 . As a result, the lower the local indicator index, the more consistent the voltage stability.

\subsection{Economic: cost analysis}

In this research, the system's daily cost is evaluated for examination. When compared to the price of electricity consumed from the electric grid, the daily operation and maintenance expenditures of renewables [39] are negligible. In this analysis, the prices of power acquired from the grid are based on a dynamic scheme. To calculate daily operation costs, compute the daily power used from the grid and multiply it by the dynamic rates of electricity.

\section{PROPOSED TECHNO- ECONOMIC ANALYSIS METHODOLOGY}

The main objective of the paper is to analyse the voltage stability of the test system and the price of power purchased from the grid [40]-[49]. In this section, the step-by-step procedure for evaluating the Techno-Economic analysis is presented. The presented techno-economic assessment of the standard test system (IEEE 14 and IEEE 30 bus) and Modified test system (with solar PV, Wind and STATCOM) are considered. The Algorithm contains 6 steps which involves Newton Raphson and L-Index calulation using MATLAB Coding Environment.

Step1: Consider a standard test system in which the Techno-Economic Analysis has to be carried out. In our paper, IEEE 14 and IEEE 30 bus system are used for Analysis.

Step2: Perform Newton Raphson Load Flow Analysis on the Standard Test system [50] (IEEE-14 and 30 bus system) [51]

Step 3: Find the L-Index value for each load bus

Step 4: Find the cost of the power purchased from the grid to meet the load demand of the system. When considering the price of energy acquired from the grid, the daily $\mathrm{O} \& \mathrm{M}$ costs of renewable sources are negligible.

Step 5: Identify the suitable bus to which the Renewable [52]-[56] and STATCOM can be added considering the following factors

i) Heavy Load demand

ii) Identify Weakest bus using L-Index calculation

Step 6: Modify the standard test system (IEEE 14 and 30 bus) by incorporating RES (PV and WIND)

\section{RESULTS AND INFERENCES}

In this part, the Techno-Economic analysis is done for two different IEEE standard system (IEEE 14 bus and IEEE 30 bus) and three cases for each IEEE standard system [57]. The case1 is the comparative technical analysis of standard test system (IEEE 14 and IEEE 30) and Modified test system. Case 2 is the comparative technical analysis of standard (IEEE 14 and IEEE 30) bus system with the modified system with hourly 1 day load. Cost of the electricity purchased - IEEE 14 bus system - 1 day load is considered for case 3 . The results are depicted with the help of Table and Graph.

\subsection{Test system 1: IEEE 14 bus}

- Case 1: Comparative technical analysis of standard IEEE 14 bus system with the Modified-IEE 14 bus system.

The Table 1 shows the comparative technical analysis of IEEE 14 bus system [58] with the modified IEEE-14 bus system after adding photovoltaic (PV) and Wind to the bus 9 and bus 11 respectively. The renewable energy sources (PV and Wind) is incorporated to the standard IEEE 14 bus system [59]-[61]. The L-index of the load buses 4,5,7,9,10,11,12,13 and 14 are found using (1).

Table 1. Comparative L-Index values of IEEE 14 bus with standard load

\begin{tabular}{ccc}
\hline Bus No & L-Index of Standard IEEE-14 bus & L-Index of Modified IEEE-14 bus \\
\hline 4 & 0.0976 & 0.0912 \\
5 & 0.2389 & 0.1762 \\
7 & 0.1083 & 0.0891 \\
9 & 0.3287 & 0.1572 \\
10 & 0.3198 & 0.1653 \\
11 & 0.1498 & 0.0971 \\
12 & 0.0926 & 0.0521 \\
13 & 0.1265 & 0.0763 \\
14 & 0.3969 & 0.1072 \\
\hline
\end{tabular}


- Case 2: Comparative technical analysis of standard IEEE 14 bus system with the Modified-IEE 14 bus system with hourly 1 day load

The graph as shown in Figure 1(a) depicts the L-Index of all the 14 buses for 24 hours. X-axis indicates the hours (24 hours) and the $\mathrm{Y}$ axis implies the L-Index value and the graph as shown in Figure 1(b) depicts the L-Index of all the 14 buses for 24 hours. X-axis indicate the hours ( 24 hours) and the Y axis express the L-Index value.

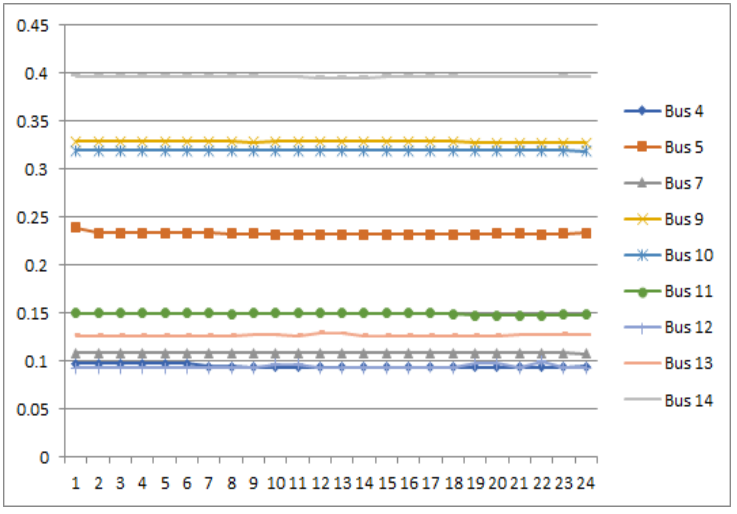

(a)

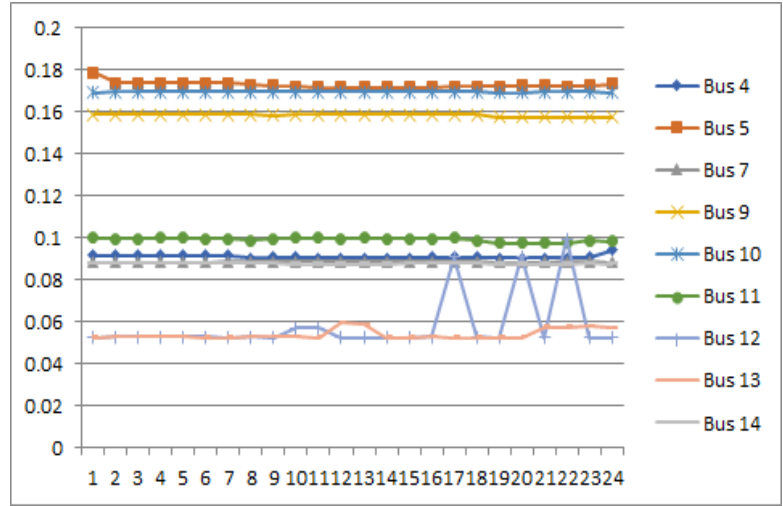

(b)

Figure 1. (a) L-Index of IEEE-14 bus for 1-day hourly load and (b) L-Index of modified IEEE-14 bus for 1-day hourly load

- Case 3: Cost of the electricity purchased-IEEE 14 bus system-1 day load

The Table 2 shows the price of the Electricity acquired from grid by IEEE 14 bus system and Modified IEEE-14 bus system [62]. The Total cost of the Electricity purchased from the grid by IEEE 14 bus system for a single day are 113616.44 Euro. The total cost of electricity purchased by Modified IEEE 14 bus system from the grid for a single day are 150567.80 Euro.

Table 2. Cost of electricity purchased from grid during each hour (in Euro)

\begin{tabular}{cccccc}
\hline Hour & Cost of IEEE-14 bus & Cost of Modified IEEE-14 bus & Hour & Cost of IEEE-14 bus & Cost of Modified IEEE-14 bus \\
\hline 1 & 3042.22 & 533.68 & 13 & 6381.23 & 5943.14 \\
2 & 2677.97 & 1266.22 & 14 & 6189.99 & 2903.95 \\
3 & 2490.39 & 1625.13 & 15 & 5733.17 & 0 \\
4 & 2384.4 & 1594.09 & 16 & 5424.62 & 2422.93 \\
5 & 2385.21 & 1776.26 & 17 & 5317.67 & 4604.81 \\
6 & 2642.03 & 2151.76 & 18 & 5565.9 & 4892.92 \\
7 & 3313.43 & 3098.84 & 19 & 5637.79 & 4986.63 \\
8 & 4744.78 & 4575.76 & 20 & 5780.69 & 5580.71 \\
9 & 5727.73 & 5259.14 & 21 & 5808.45 & 5130.28 \\
10 & 6157.52 & 4160.01 & 22 & 5263.72 & 5083.58 \\
11 & 6385.5 & 4342.55 & 23 & 4525.44 & 3966.71 \\
12 & 6467.24 & 4504.58 & 24 & 3569.36 & 3036.86 \\
\hline
\end{tabular}

\subsection{Test system 2: IEEE 30 bus}

- Case 1: Comparative technical analysis of standard IEEE 30 bus system with the Modified-IEE 30 bus system.

The Table 3 shows the comparative technical analysis of IEEE 30 bus system [63]-[65] with the modified IEEE-30 bus system after adding PV and Wind to the bus 25 and bus 7 respectively. The renewable energy sources (PV and Wind) is incorporated to the standard IEEE 30 bus system. The L-index of the load buses 3,4,6,7,9,10,12,14,15,16,17,18,19-30 are found using (1).

- Case 2: Comparative Technical Analysis of Standard IEEE 30 bus system with the Modified-IEE 14 bus system with hourly 1 day load

The graph as shown in Figure 2(a) depicts the L-Index of all load buses for 24 hours. X-axis implies the hours (24 hours) and the Y axis refers to the L-Index value and the graph as shown in Figure 2(b) depicts the L-Index of all the load buses for 24 hours. X-axis express the hours ( 24 hours) and the Y axis indicates the L-Index value. 
Table 3. Comparative L-Index values of IEEE 30 bus with standard load

\begin{tabular}{cccccc}
\hline $\begin{array}{c}\text { Bus } \\
\text { No }\end{array}$ & $\begin{array}{c}\text { L-Index of Standard } \\
\text { IEEE-30 bus }\end{array}$ & $\begin{array}{c}\text { L-Index of Modified } \\
\text { IEEE-30 bus }\end{array}$ & $\begin{array}{c}\text { Bus } \\
\text { No }\end{array}$ & $\begin{array}{c}\text { L-Index of Standard } \\
\text { IEEE-30 bus }\end{array}$ & $\begin{array}{c}\text { L-Index of Modified } \\
\text { IEEE-30 bus }\end{array}$ \\
\hline 3 & 0.0643 & 0.0337 & 19 & 0.2387 & 0.1162 \\
4 & 0.1831 & 0.1741 & 20 & 0.0731 & 0.0668 \\
6 & 0.3552 & 0.2314 & 21 & 0.0432 & 0.0231 \\
7 & 0.0412 & 0.0196 & 22 & 0.1721 & 0.0632 \\
9 & 0.3538 & 0.1436 & 23 & 0.2368 & 0.0165 \\
10 & 0.1347 & 0.0916 & 24 & 0.1299 & 0.0881 \\
12 & 0.1277 & 0.0842 & 25 & 0.0876 & 0.0747 \\
14 & 0.3276 & 0.1890 & 26 & 0.0652 & 0.0476 \\
15 & 0.4531 & 0.3171 & 27 & 0.0332 & 0.0113 \\
16 & 0.2176 & 0.0468 & 28 & 0.1961 & 0.0954 \\
17 & 0.1153 & 0.0883 & 29 & 0.1138 & 0.0873 \\
18 & 0.0972 & 0.0756 & 30 & 0.0921 & 0.0835 \\
\hline
\end{tabular}

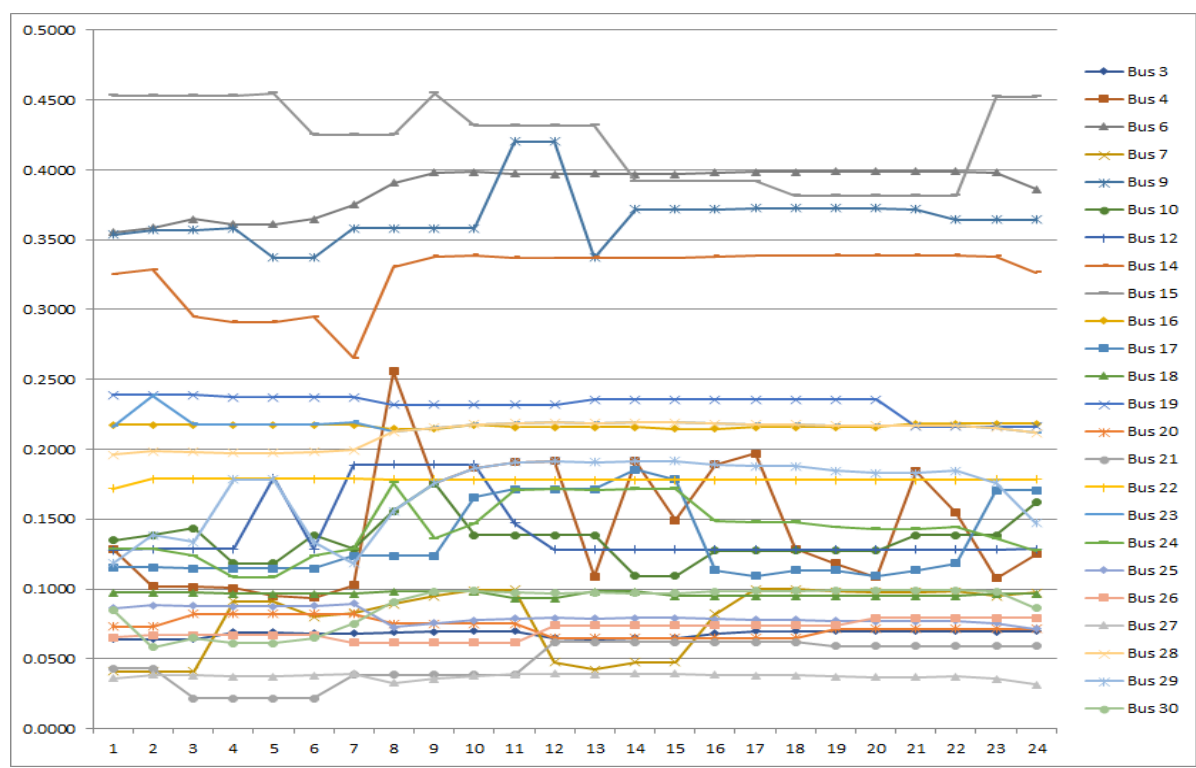

(a)

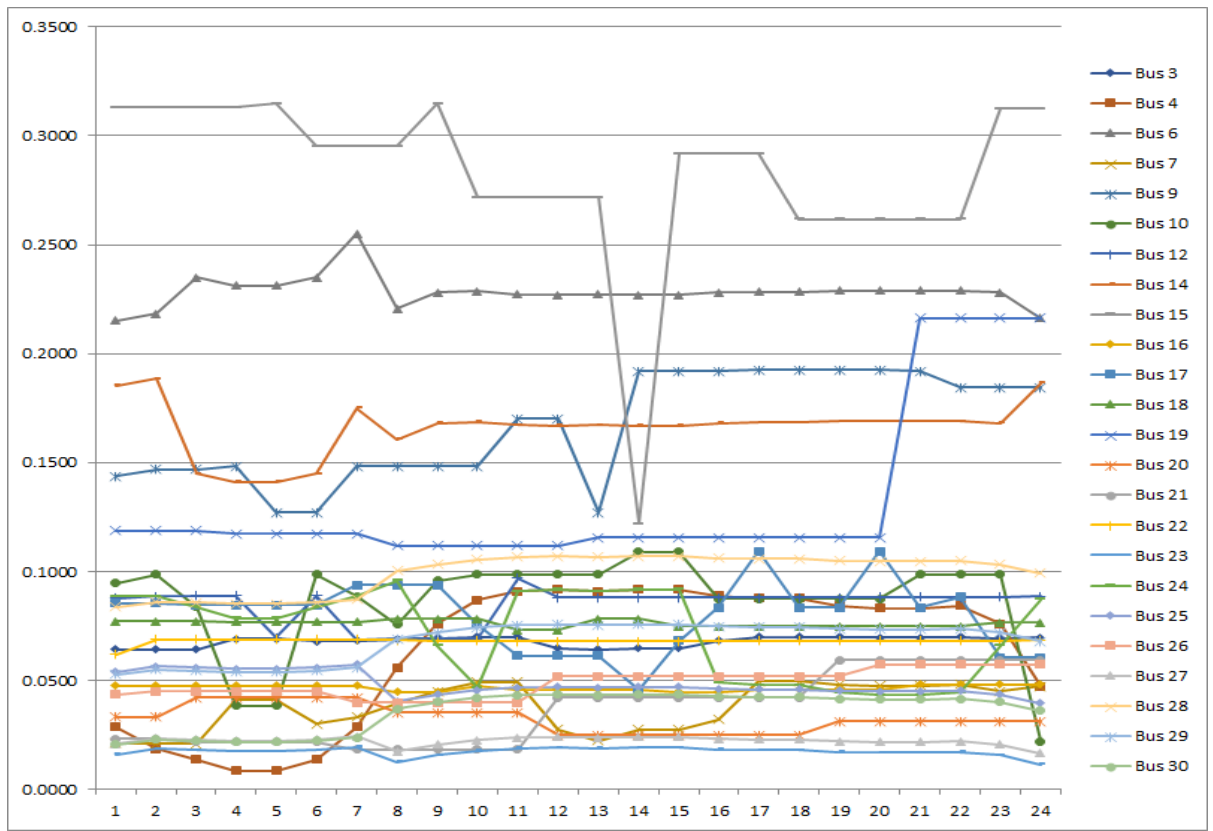

(b)

Figure 2. (a) L-Index of IEEE-30 bus for 1-day hourly load and (b) L-Index of Modified IEEE-30 bus for 1day hourly load 
- Case 3: Cost of the electricity purchased-IEEE 30 bus system-1 day load

The Table 4 shows the price of the electricity acquired from grid by IEEE 30 bus system and modified IEEE-30 bus system. The Total price of the electricity purchased from the grid by IEEE 30 bus system for a single day are 99770.96 Euro. The total price of electricity purchased by Modified IEEE 30 bus system from the grid for a single day are 70293.72 Euro.

Table 4. Cost of electricity purchased from grid during each hour (in Euro)

\begin{tabular}{cccccc}
\hline Hour & Cost of IEEE-30 bus & Cost of Modified IEEE-30 bus & Hour & Cost of IEEE-30 bus & Cost of Modified IEEE-30 bus \\
\hline 1 & 2671.49 & 162.95 & 13 & 5603.6 & 5165.51 \\
2 & 2351.63 & 939.87 & 14 & 5435.67 & 2149.63 \\
3 & 2186.91 & 1321.65 & 15 & 5034.52 & 0 \\
4 & 2093.83 & 1303.52 & 16 & 4763.57 & 1761.88 \\
5 & 2094.54 & 1485.6 & 17 & 4669.65 & 3956.79 \\
6 & 2320.07 & 1829.8 & 18 & 4887.63 & 4214.65 \\
7 & 2909.65 & 2695.06 & 19 & 4950.76 & 4299.6 \\
8 & 4166.58 & 3997.55 & 20 & 5076.25 & 4876.27 \\
9 & 5029.74 & 4561.15 & 21 & 5100.62 & 4422.45 \\
10 & 5407.16 & 3409.65 & 22 & 4622.27 & 4442.14 \\
11 & 5607.35 & 3564.41 & 23 & 3973.96 & 3415.23 \\
12 & 5679.13 & 3716.47 & 24 & 3134.39 & 2601.89 \\
\hline
\end{tabular}

\section{CONCLUSION}

With and without the integration of renewable energy sources, the voltage stability - in terms of Lindices of load buses-and the price of Electric power consumed from grid were computed (PV and Wind). The analysis is carried out for two standard IEEE system (IEEE 14 bus and IEEE 30 bus) and the following observations were made. In IEEE 14 bus system, on comparing the voltage stability index of the IEEE 14 bus with and without the incorporation of RES, there is an average of $38 \%$ improvement in the stability of the system when PV and Wind is added to the standard system. The price of electricity acquired from the grid is lowered by $33 \%$ when the RES is added to the system. In IEEE 30 bus system, on comparing the voltage stability index of the IEEE 30 bus with and without the incorporation of RES, there is an average of $34 \%$ enhancement in the stability of the system when PV and Wind is added to the standard system. The price of electricity acquired from the grid is lowered by $30 \%$ when the RES is incorporated to the system. Overall, the voltage profile, voltage stability and the cost analysis show a considerable increment in both voltage stability and economic aspects of the system when RES is incorporated.

\section{REFERENCES}

[1] A. Qazi et al., "Towards Sustainable Energy: A Systematic Review of Renewable Energy Sources, Technologies, and Public Opinions," IEEE Access, pp. 63837-63851, 2019, doi: 10.1109/ACCESS.2019.2906402.

[2] U. S. Zad and Riphah, "Global Warming: Causes, Effects and Solutions," Durreesamin Journal, August, vol. 1, no. $4,2015$.

[3] C. S. Indulkar and K. Ramalingam, "Load flow Analysis with Voltage-Sensitive Loads," 2008 Joint International Conference on Power System Technology and IEEE Power India Conference, Jan 2009, doi: 10.1109/ICPST.2008.4745151.

[4] S. Chatterjee and S. Mandal," A Novel comparison of Gauss-seidel and Newton Raphson Methods for Load Flow Analysis," IEEE-International Conference on Power and Embedded Drive control (ICPEDC), 2017, doi: 10.1109/ICPEDC.2017.8081050.

[5] S. Gaddameedhi, and P. Srinivas, "A novel fuzzy based controller to reduce circulating currents in parallel interleaved converter connected to the grid," International Journal of Electrical and Computer Engineering, vol. 11, no. 2, pp. 1130-1142, 2021, doi: 10.11591/ijece.v11i2.pp1130-1142.

[6] A. Javadian, M. Zadehbagheri, M. J. Kiani, S. Nejatian, and T. Sutikno, "Modeling of static var compensator-high voltage direct current to provide power and improve voltage profile," International Journal of Power Electronics and Drive Systems, vol. 12, no. 3, 2021, pp. 1659-1672, doi: 10.11591/ijpeds.v12.i3.pp1659-1672.

[7] A. Alizadeh Asl and R. Alizadeh Asl, "Modeling and control of a hybrid dc/dc/ac converter to transfer power under different power management strategies," International Journal of Power Electronics and Drive Systems, vol. 12, no. 3, 2021, pp. 1620-1631, doi: 10.11591/ijpeds.v12.i3.pp1620-1631.

[8] S. M. Abbasi, M. Nafar, and M. Simab, "Performance improvement of decentralized control for bidirectional converters in a DC micro-grid," International Journal of Power Electronics and Drive Systems, vol. 12, no. 3, pp. 1505-1520, 2021, doi: 10.11591/ijpeds.v12.i3.pp1505-1520.

[9] S. R. Salkuti, and N. R. Battu, "An effective network reconfiguration approach of radial distribution system for loss minimization and voltage profile improvement," Bulletin of Electrical Engineering and Informatics, vol. 10, no. 4, pp. 1819-1827, 2021, doi: 10.11591/eei.v10i4.2867. 
[10] J. Modarresi, E. Gholipour, and A. Khodabakhshian, "A Comprehensive Review of the Voltage stability indices," Renewable and Sustainable Energy Reviews-Elsevier, vol. 63, pp. 1-12, Sept 2016, doi: 10.1016/j.rser.2016.05.010.

[11] T. A. F. Ram, and K. M. Haneesh, "Voltage stability analysis using L-index under various transformer tap changer settings," International Conference on Circuit, Power and Computing Technologies (ICCPCT), 2016, doi: 10.1109/ICCPCT.2016.7530331.

[12] P. Kessel and Glavitsch, "Estimating the Voltage Stability of a Power system," IEEE transaction on Power Delivery, vol. PWRD-1, no. 3, July 1996, doi: 10.1109/TPWRD.1986.4308013.

[13] M. A. Perez, A. R. Messina, and C. R. Fuerte- Esquivel, "Application of FACTS devices to improve steady-state voltage stability," IEEE-Power Engineering Society Summer Meeting, July 2000.

[14] Q. Alsafasfeh, O. A. Saraereh, I. Khan, and S. Kim, "Solar PV Grid Power Flow Analysis," MDPI ArticleSustainability, March 2019, doi: 10.3390/su11061744.

[15] S. S. Kumar and Thukaram, "Accurate modelling of doubly fed induction generator-based wind farms in load flow analysis," Elsevier-Electric Power systems research, June 2017.

[16] M. Q. Taha, "Advantages and recent advances of smart energy grid," Bulletin of Electrical Engineering and Informatics, vol. 9, no. 5, pp. 1739-1746, 2020, doi: 10.11591/eei.v9i5.2358.

[17] A. M. Yasin and M. F. Alsayed, "Fuzzy logic power management for a PV/wind microgrid with backup and storage systems," International Journal of Electrical and Computer Engineering, vol. 11, no. 4, pp. 2876-2888, 2021, doi: 10.11591/ijece.v11i4.pp2876-2888.

[18] I. M. Wartana, N. P. Agustini, and S. Sreedharan, "Optimal integration of wind energy with a shunt-FACTS controller for reductions in electrical power loss," Indonesian Journal of Electrical Engineering and Computer Science, vol. 23, no. 1, 2021, doi: 10.11591/ijeecs.v23.i1.pp41-53.

[19] F. A. Ayoade, A. Ademola, H. E. Orovwode, K. O. Oluwafemi, M. Simeon, and A. A. Oluranti, "Power quality considerations for embedded generation integration in Nigeria: A case study of ogba $33 \mathrm{kV}$ injection substation," International Journal of Electrical and Computer Engineering, vol. 11, no. 2, pp. 956-965, 2021, doi: 10.11591/ijece.v11i2.pp956-965.

[20] J. Kumar, N. R. Parhyar, M. K. Panjwani, and D. Khan, "Design and performance analysis of PV grid-tied system with energy storage system," International Journal of Electrical and Computer Engineering, vol. 11, no. 2, pp. 1077-1085, 2021, doi: 10.11591/ijece.v11i2.pp1077-1085.

[21] U. Sultana, S. H. Qazi, N. Rasheed, and M. W. Mustafa, "Performance analysis of real-time PSO tuned PI controller for regulating voltage and frequency in an AC microgrid," International Journal of Electrical and Computer Engineering, vol. 11, no. 2, pp. 1068-1076, 2021, doi: 10.11591/ijece.v11i2.pp1068-1076.

[22] E. M. Abdallah, M. I. Elsayed, M. M. ELgazzer, and A. A. Hassan, "Coyote multi-objective optimization algorithm for optimal location and sizing of renewable distributed generators," International Journal of Electrical and Computer Engineering, vol. 11, no. 2, 2021, pp. 975-983, doi: 10.11591/ijece.v11i2.pp975-983.

[23] M. Benyamina, A. Tahri, A. Boukortt, "State feedback control of advanced static var compensator using a fivelevel npc inverter topology," International Journal of Power Electronics and Drive Systems, vol. 12, no. 1, pp. 345-355, 2021, doi: 10.11591/ijpeds.v12.i1.pp345-355.

[24] T. Noureddine, and L. Djamel, "Load flow analysis using newton raphson method in presence of distributed generation," International Journal of Power Electronics and Drive Systems, vol. 12, no. 1, 2021, pp. 489-498, doi: 10.11591/ijpeds.v12.i1.pp489-498.

[25] E. Radwan, M. Nour, A. Baniyounes, K. S. Al-Olimat, and E. Awada, "Direct control of active and reactive power for a grid-connected single-phase photovoltaic inverter," International Journal of Power Electronics and Drive System, vol. 12, no. 1, pp. 139-150, doi: 10.11591/ijpeds.v12.i1.pp139-150.

[26] K. Sivakumar, R. Jayashree, and K. Danasagaran, "A novel branch current flow-based construction of microgrids," Indonesian Journal of Electrical Engineering and Computer Science, vol. 21, no. 1, pp. 28-36, 2021, doi: 10.11591/ijeecs.v21.i1.pp28-36.

[27] M. S. Alatshan, I. Alhamrouni, T. Sutikno, and A. Jusoh, "Improvement of the performance of statcom in terms of voltage profile using ann controller," International Journal of Power Electronics and Drive Systems, vol. 11, no. 4, pp. 1966-1978, 2020, doi: 10.11591/ijpeds.v11.i4.pp1966-1978.

[28] A. J. Ali, M. Y. Suliman, L. A. Khalaf, and N. S. Sultan, "Performance investigation of stand-alone induction generator based on STATCOM for wind power application," International Journal of Electrical and Computer Engineering, vol. 10, no. 6, pp. 5570-5578, 2020, doi: 10.11591/ijece.v10i6.pp5570-5578.

[29] Y. Sychev, B. Abramovich, and V. Prokhorova, "The assesement of the shunt active filter efficiency under varied power supply source and load parameters," International Journal of Electrical and Computer Engineering, vol. 10, no. 6, pp. 5621-5630, 2020, doi: 10.11591/ijece.v10i6.pp5621-5630.

[30] M. H. Khan, S. A. Zulkifli, E. Pathan, E. Garba, R. Jackson, and H. Arshad, "Decentralize power sharing control strategy in islanded microgrids," Indonesian Journal of Electrical Engineering and Computer Science, vol. 20, no. 2, pp. 752-760, 2020, doi: 10.11591/ijeecs.v20.i2.pp752-760.

[31] B. Abdelkader and L. Djamel, "Contribution of DGS in the stability and voltage drop reduction for future MV network in desert regions," International Journal of Power Electronics and Drive Systems, vol. 11, no. 2, pp. 977-987, 2021, doi: 10.11591/ijpeds.v11.i2.pp977-987.

[32] N. Pati and B. Panda, "Stability analysis of photovoltaic system under grid faults," International Journal of Power Electronics and Drive Systems, vol. 11, no. 2, pp. 931-941, 2020, doi: 10.11591/ijpeds.v11.i2.pp931-941. 
[33] S. Janjornmanit, S. Panta, and V. Thonglek, "An approach of controlling the inverter-based generator for use in an Islanded microgrid," International Journal of Power Electronics and Drive Systems, vol. 11, no. 3, pp. 1610-1616, 2020, doi: 10.11591/ijpeds.v11.i3.pp1610-1616.

[34] S. I. Khather, "Nonlinear control of gti for stabilizing future smart grids", International Journal of Power Electronics and Drive Systems, vol. 11, no. 3, pp. 1268-1277, 2020, doi: 10.11591/ijpeds.v11.i3.pp1268-1277.

[35] S. R. Salkuti, "Artificial fish swarm optimization algorithm for power system state estimation," Indonesian Journal of Electrical Engineering and Computer Science, vol. 18, no. 3, 2020, pp. 1130-1137, doi: 10.11591/ijeecs.v18.i3.pp1130-1137.

[36] O. P. Rahi, A. K. Yadav, H. Malik, A. Azeem, and B. Kr, "Power system Voltage stability Assessment through Artificial Neural Network," Procedia Engineering- Elsevier, vol. 30, pp. 53-60, 2012, doi: 10.1016/j.proeng.2012.01.833.

[37] B. Gao, G. K. Morison, and P. Kundur, "Voltage Stability Evaluation using Modal Analysis," Transaction on Power Systems, vol. 7, no. 4. November 1992, doi: 10.1109/59.207377.

[38] C. Reis and F. P. M. Barbosa, "A Comparison of Voltage Stability Indices," International Conference on Power System Technology, IEEE MELECON, May 2006.

[39] F. C. C. Li, and F. de bosio, "Economic Dispatch for operating cost minimization under real-time pricing in droopcontrolled dc microgrid," IEEE Journal of Emerging and Selected Topics in Power Electronics, vol. 5, pp. 587-595, 2016, doi: 10.1109/JESTPE.2016.2634026.

[40] N. A. Shalash and Y. N. Lafta, "PSS/E based placement wind/PV hybrid system to improve stability of Iraqi grid," International Journal of Electrical and Computer Engineering, vol. 10, no. 1, 2020, pp. 91-104, doi: 10.11591/ijece.v10i1.pp91-104.

[41] G. Sureshkumaar, N. Kannan, and S. Thomas, "MATLAB/SIMULINK based simulations of KY converter for PV panels powered led lighting system," International Journal of Power Electronics and Drive System, vol. 10, no. 4, pp. 1885-1893, 2019, doi: 10.11591/ijpeds.v10.i4.pp1885-1893.

[42] N. Khuan, S. R. A. Rahim, M. H. Hussain, A. Azmil, and S. A. Azmi, "Integration of distributed generation and compensating capacitor in radial distribution system via firefly algorithm," Indonesian Journal of Electrical Engineering and Computer Science, vol. 16, no. 1, pp. 67-73, 2019, doi: 10.11591/ijeecs.v16.i1.pp67-73.

[43] M. M. Almelian et al., "Enhancing the performance of cascaded three-level VSC STATCOM by ANN controller with SVPWM integration,” International Journal of Electrical and Computer Engineering, vol. 9, no. 5, 2019, pp. 3880-3890, doi: 10.11591/ijece.v9i5.pp3880-3890.

[44] N. A. Rohman, N. F. A. Rahman, and M. A. A. M. Zainuri, "Characteristics of lead-acid and nickel metal hydride batteries in uninterruptible power supply operation," International Journal of Power Electronics and Drive Systems, vol. 3, no. 10, pp. 1520-1528, 2019, doi: 10.11591/ijpeds.v10.i3.pp1520-1528.

[45] N. Karthik, A. K. Parvathy, R. Arul, and S. Baskar, "A review of optimization techniques applied to solve unit commitment problem in microgrid," Indonesian Journal of Electrical Engineering and Computer Science, vol. 15, no. 3, pp. 1161-1169, 2019, doi: 10.11591/ijeecs.v15.i3.pp1161-1169.

[46] A. A. Tadjeddine, A. Chaker, M. Khiat, L. Abdelmalek, and N. Khalfalah, "A contribution to the control of voltage and power of the interconnection between two decentralized electrical grids with an optimal localization of the SVC devices in real-time," International Journal of Power Electronics and Drive Systems, vol. 10, no. 1, 2019, pp. 170-177, doi: 10.11591/ijpeds.v10.i1.pp170-177.

[47] T. Hamza, M. F. Zahra, and K. Boufeldja, "Robust optmized control of multi levels STATCOM," Indonesian Journal of Electrical Engineering and Computer Science, vol. 16, no. 3, 2019, pp. 1203-1212, doi: 10.11591/ijeecs.v16.i3.pp1203-1212.

[48] I. A. Ethmane, A. K. Mahmoud, M. Maaroufi, and A. Yahfdhou, "Transient stability enhancement of statcom integration in power grid," Indonesian Journal of Electrical Engineering and Computer Science, vol. 16, no. 2, pp. 553-561, 2019, doi: 10.11591/ijeecs.v16.i2.pp553-561.

[49] S.-C. Kim and S. R. Salkut, "Optimal power flow based congestion management using enhanced genetic algorithms," International Journal of Electrical and Computer Engineering, vol. 9, no. 2, pp. 875-883, 2019, doi: 10.11591/ijece.v9i2.pp875-883.

[50] O. A. Afolabi, W. H. Ali, P. Cofie, J. Fuller, P. Obiomon, and E. S. Kolawole, "Analysis of the Load Flow Problem in Power System Planning Studies," Energy and Power Engineering, vol. 7 no. 10, 2015, doi: 10.4236/epe.2015.710048.

[51] B. U. Musa and M. Mustapha, "Modelling and Simulation of STATCOM for Reactive Power and Voltage Control," Journal of Multidisciplinary Engineering Science and Technology (JMEST), vol. 2, no. 2, Feb 2015.

[52] S. Gupta, S. Garg, V. Babbar, S. Saha, and N. Nagarwal, "Modeling \& Performance Investigation of PV Integrated IEEE 14 Bus Test System," International Conference on Computing, Power and Communication Technologies (GUCON), 2018, doi: 10.1109/GUCON.2018.8674923.

[53] Federal oce for building and regional planning in Germany." Accessed: 4 Nov. 2017. [Online]. Available: http://www.bbsr.bund.de/EnEVPortal/DE/Regelungen/Testreferenzjahre/Testreferenzjahre/03_ergebnis se.html?nn=436654..

[54] Eex. Accessed: 06 Nov. 2017. [Online]. Available: https://www.eex.com/de/marktdaten/strom/spotmarkt/auktion \#! / 2017/09/01

[55] Tesla powerwall 2.0 dc. Accessed: $07 \quad$ Nov. 2017. [Online]. Available: https://www.solahart.com.au/media/2849/powerwall-2-dc_datasheet_english.pdf

[56] H. J. Queen and J. Jayakumar, "Operating Cost Analysis of a Microgrid including Renewable Energy Sources without considering the losses," International Journal of Pure and Applied Mathematics, vol. 118, no. 20, pp. 745-750, 2018. 
[57] B. Divya, and Devarapalli, "Estimation of sensitive node for IEEE-30 bus system by load variation," International Conference on Green Computing Communication and Electrical Engineering (ICGCCEE-2014), pp. 1-4, 2014, doi: 10.1109/ICGCCEE.2014.6922357.

[58] Bansilal, D. Thukaram and K. Parthasarathy, "Optimal reactive power dispatch algorithm for voltage stability improvement," Elsevier, 1996, doi: 10.1016/0142-0615(96)00004-X.

[59] N. Lermer, "Operating cost analysis of microgrid including renewable energy sources and a battery under dynamic pricing," Oct- Nov 2017.

[60] P. Kessel, and Glavitsch, "Estimating the Voltage Stability of a Power system," IEEE transaction on Power Delivery, vol. PWRD-1, no. 3, July 1996, doi: 10.1109/TPWRD.1986.4308013.

[61] Y. Muñoz, A Ospino, C. Robles, and C. Arizmendi, "Implementation of a frequency control in a biomass gasifier system," International Journal of Electrical and Computer Engineering, vol. 9, no. 1, pp. 66-77, 2019, doi: 10.11591/ijece.v9i1.pp66-77.

[62] K. Paul and N. Kumar, "Cuckoo search algorithm for congestion alleviation with incorporation of wind farm," International Journal of Electrical and Computer Engineering, vol. 8, no. 6, pp. 4871-4879, 2018, doi: 10.11591/ijece.v8i6.pp4871-4879.

[63] R. Verayiah and A. Mohamed, "Comparison of weak load bus detection using LQP_LT index with PV and QV analysis of PSS/E," Indonesian Journal of Electrical and Computer Science, vol. 12, no. 2, pp. 577-584, 2018, doi: 10.11591/ijeecs.v12.i2.pp577-584.

[64] S. H. Qazi and M. W. Mustafa, "Improving voltage profile of islanded microgrid using PI controller," International Journal of Electrical and Computer Engineering, vol. 8, no. 3, pp. 1383-1388, 2018, doi: 10.11591/ijece.v8i3.pp1383-1388.

[65] N. M. Saad et al., "Impacts of photovoltaic distributed generation location and size on distribution power system network," International Journal of Power Electronics and Drive Systems, vol. 9, no. 2, pp. 905-913, 2018, doi: 10.11591/ijpeds.v9.i2.pp905-913.

\section{BIOGRAPHIES OF AUTHORS}
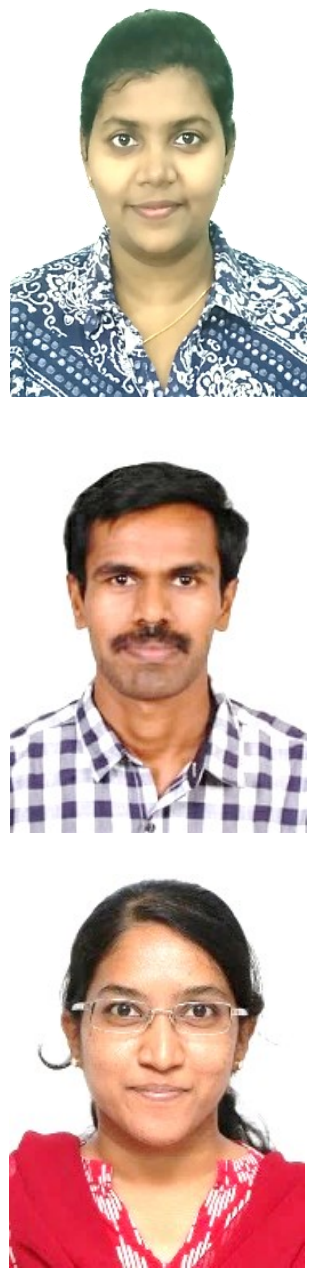

Hephzibah Jose Queen received M.E (Power systems Engineering) from Valliammai Engineering College-Anna University, Chennai, 2013 and B.E (Electrical and Electronics Engineering) from Karunya University, Coimbatore in 2011. Currently, she is a Research Scholar in the Department of Electrical and Electronics Engineering at Karunya University, Coimbatore, India. She has published many research papers in international journals and conferences. Her research field of interest includes Smart Grid, Power system Analysis, Machine Learning, and improvement of Power Quality with FACTS devices.

Jayakumar J. received his $\mathrm{PhD}$ degree from Anna University, Chennai in 2010, and M.E. degree from Madurai Kamaraj University, Madurai in 2002 and B.E degree from Bharathiar University, Coimbatore in 1999. Currently, he is working as Associate professor in Department of Electrical and Electronics Engineering at Karunya University, Coimbatore, India. He has published many research papers in international journals and conferences. His research field of interest includes multimedia systems, Cloud Computing, smart Grid, power system analysis, generation and distribution, control and modeling of the power system with flexible ac transmission systems (FACTS).

Deepika T. J. received her PhD degree in Electrical Engineering Electrical Engineering from Anna University, Chennai in 2019, M.Tech. degree in Power Systems from SRM University, Chennai in 2014 and B.E degree in Electrical and Electronics Engineering from Karunya University, Coimbatore in 2011. She is presently working as Assistant professor in Department of Electrical and Electronics Engineering at Sona College of Technology, Salem, India. Her areas of expertise include, power systems, solar photovoltaics, distribution system, hybrid renewable distributed generation, smart grid, deregulated power market, soft computing, machine learning, data analytics using python. 